\title{
PEMETAAN SUMBER PENCEMAR SUNGAI LAMAT KABUPATEN MAGELANG
}

\author{
Ristie Ermawati ${ }^{1)}$, Lono Hartanto ${ }^{2)}$ \\ 1) Prodi Teknik Lingkungan Akademi Teknik Tirta Wiyata Magelang \\ ${ }^{2)}$ Badan Lingkungan Hidup Kabupaten Magelang \\ E-mail : ristie.ermawati@akatirta.ac.id
}

\begin{abstract}
Abstrak
Sungai Lamat merupakan salah satu sungai yang ada di Kabupaten Magelang yang berpotensi mengalami pencemaran. Pencemaran sungai ini dapat mengakibatkan terganggunya ekosistem sungai dan dapat merugikan masyarakat yang memanfaatkan sungai tersebut. Pencemaran sungai dapat dikendalikan dengan cara inventarisasi dan pemetaan sumber pencemar yang berpotensi mencemari Sungai Lamat dan penentuan status mutu air Sungai Lamat. Pemetaan sumber pencemar dilakukan dengan mengolah data yang diperoleh dengan menggunakan Sistem Informasi Geografis. Penentuan status mutu air dilakukan dengan menggunakan metode Indeks Pencemaran (KepMen LH No. 115 Tahun 2003). Hasil penelitian menunjukkan bahwa Sungai Lamat berpotensi tercemar oleh limbah rumah tangga dan limbah industri, baik yang berupa limbah cair maupun limbah padat. Berdasarkan penentuan status mutu air menggunakan Metode Indeks Pencemaran, status mutu air Sungai Lamat dari tahun ke tahun bervariasi, dari “baik” hingga “cemar ringan”.
\end{abstract}

Kata Kunci: Pemetaan, Pencemaran Air, Sumber Pencemar, Sungai Lamat

\begin{abstract}
Lamat River, located in Magelang Regency, has a potential to contamination. A contaminated river is not only hazardous for the ecosystem but also for the people who use the river. River pollution can be controlled using the inventory and mapping of pollutant sources that potentially contaminate the Lamat River as well as the determination of water quality status of Lamat River. The mapping of pollutant sources was conducted by processing the data collected using GIS (Geographic Information System). The water quality status was determined using Pollution Index Method (KepMen LH No. 115 Year 2003). The result shows that the Lamat River is potentially contaminated by household and industrial wastes, both in the form of liquid and solid wastes. Based on the determination of water quality status using Pollution Index Method, the status of water quality of Lamat River varies from year to year, from 'good' to 'mildly contaminated'.
\end{abstract}

Keywords: mapping, pollution source, water pollution, Lamat River

\section{PENDAHULUAN}

Air merupakan salah satu kebutuhan vital bagi manusia. Keberadaan air di bumi selalu terjaga dengan adanya siklus hidrologi. Akan tetapi bukan berarti jumlah air yang dapat dimanfaatkan manusia tidak terbatas. Keberlangsungan siklus hidrologi dapat terganggu akibat adanya kerusakan Daerah Aliran Sungai (DAS). DAS merupakan daerah yang dibatasi punggung-punggung gunung dimana air hujan yang jatuh pada daerah tersebut akan ditampung oleh punggung gunung tersebut dan akan dialirkan melalui sungai-sungai kecil ke sungai utama (Asdak, 2010). Selain terganggunya siklus hidrologi, 
pencemaran air juga merupakan penyebab terbatasnya air yang dapat dimanfaatkan oleh manusia. Menurut UU No 82 Tahun 2001, yang dimaksud pencemaran lingkungan air adalah masuk atau dimasukkannya makhluk hidup, zat, energi, dan/atau komponen lain ke dalam air oleh kegiatan manusia, sehingga kualitas air turun sampai ke tingkat tertentu yang menyebabkan air tidak dapat berfungsi sesuai dengan peruntukannya.

Sumber pencemar air dapat dikelompokkan menjadi 2 berdasarkan cara masuknya (Effendi, 2003), yaitu:

a. Polutan alamiah, polutan ini masuk ke dalam badan air secara alami, misalnya akibat letusan gunung berapi, tanah longsor, banjir, dan peristiwa alam lainnya.

b. Polutan antropogenik, polutan ini masuk ke dalam badan air akibat aktivitas manusia, misalnya dari kegiatan rumah tangga, industri, pertanian, dan sebagainya.

Saat ini aktivitas manusia menjadi penyebab terbesar penurunan kualitas sungai, karena manusia menjadikan sungai sebagai tempat pembuangan sampah dan limbah tanpa melalui pengolahan terlebih dulu. Kualitas air sungai yang buruk banyak ditemui di kota-kota besar. Sungai di kota besar ini mengalami pencemaran dari limbah industri, rumah tangga, perikanan, dan lainnya. Hal ini akan berbahaya bagi kesehatan manusia yang mempergunakan air tersebut untuk kegiatan sehari-hari. Pencemaran ini juga menjadi ancaman bagi ekosistem sungai serta membuat sungai menjadi berwarna hitam, banyak sampah, dan berbau (Brontowiyono, et al., 2013; Brontowiyono, et al., 2010).

Suatu badan air harus kita ketahui status mutu airnya untuk memudahkan dalam pengelolaannya. Status mutu air merupakan tingkat kondisi mutu air yang menunjukkan kondisi cemar atau kondisi baik pada suatu sumber air dalam waktu tertentu dengan membandingkan dengan baku mutu air yang ditetapkan (KepMen LH No 115 Tahun 2003). Penentuan status mutu air dapat dilakukan dengan menggunakan Metode STORET atau Metode Indeks Pencemaran.

Kabupaten Magelang dilalui oleh 3 DAS yaitu DAS Progo, DAS Elo, dan DAS Bogowonto. Ketiga DAS tersebut terdiri dari sub-sub DAS. Sub DAS Blongkeng merupakan salah satu sub DAS yang termasuk dalam DAS Progo. Sub DAS Blongkeng melewati Kec. Muntilan, Salam, Ngluwar, Dukun, dan Srumbung. Sub-DAS Blongkeng termasuk salah satu DAS yang memiliki beban pencemaran yang tinggi sehingga dapat dimasukkan ke dalam kriteria Sub DAS kritis (BLH, 2015) Sub DAS Blongkeng 
berpotensi mengalami pencemaran akibat pembuangan limbah ke sungai tanpa adanya pengolahan terlebih dahulu. Salah satu sungai yang berpotensi mengalami pencemaran di sub DAS Blongkeng ini adalah Sungai Lamat. Pencemaran sungai ini dapat mengakibatkan buruknya kualitas sungai. Dampak dari kualitas sungai yang buruk adalah akan menurunkan jumlah biota sungai dan secara umum akan semakin menurunkan kualitas air sungai di bagian hilir yang kemudian bermuara ke laut (Yogafanny, 2015).

Pencemaran sungai dapat menyebabkan terganggunya ekosistem sungai dan dapat merugikan masyarakat yang memanfaatkan sungai tersebut. Pengendalian pencemaran sungai dapat dilakukan dengan cara inventarisasi dan pemetaan sumber pencemar yang berpotensi mencemari Sungai Lamat dan penentuan status mutu air Sungai Lamat.

\section{METODE PENELITIAN}

Penelitian ini dilakukan di daerah hulu, tengah dan hilir dari Sungai Lamat, yang berada di 2 kecamatan, yaitu Kecamatan Muntilan dan Kecamatan Dukun. Tahapan penelitian ini sebagai berikut:

\subsection{Persiapan}

Tahapan ini meliputi observasi, persiapan administrasi, koordinasi tim, serta perencanaan jadwal kegiatan.

\subsection{Pengumpulan Data}

Data yang dikumpulkan meliputi data primer dan sekunder.

- Data primer yang dikumpulkan adalah lokasi/titik koordinat sumber pencemar (baik limbah cair maupun limbah padat) Sungai Lamat.

- Data sekunder dikumpulkan dari instansi-instansi terkait, meliputi: peta administrasi Kab. Magelang, Data Kualitas Air Sungai Lamat Tahun 2005-2015, peta penggunaan lahan Kabupaten Magelang dan peta DAS Kabupaten Magelang.

\subsection{Pemetaan pencemaran Sungai Lamat}

Pemetaan sumber pencemar dilakukan dengan mengolah data yang diperoleh dengan menggunakan Sistem Informasi Geografis. 


\subsection{Penentuan Status Mutu Air Sungai Lamat}

Penentuan status mutu air dilakukan dengan menggunakan metode Indeks Pencemaran (KepMen LH No 115 Tahun 2003). Penggunaan metode Indeks Pencemaran dikarenakan terdapat perbedaan parameter kualitas air yang diukur di tiap tahunnya.

\section{HASIL DAN PEMBAHASAN}

\subsection{Deskripsi Wilayah}

Sungai Lamat merupakan salah satu sungai yang berada di Sub DAS Blongkeng. Aliran Sungai Lamat melewati dua kecamatan, dengan hulu di Kecamatan Dukun dan hilir di Kecamatan Muntilan. Sungai sepanjang 6,8 km ini juga merupakan salah satu jalur lahar dingin Gunung Merapi yang membawa material pasir dan batu. Letak Sungai Lamat secara administrasi dapat dilihat pada Gambar 1. Sungai Lamat merupakan salah satu dari 17 sungai yang berada di Sub DAS Blongkeng, letak Sungai Lamat dalam DAS Blongkeng dapat dilihat pada Gambar 2.

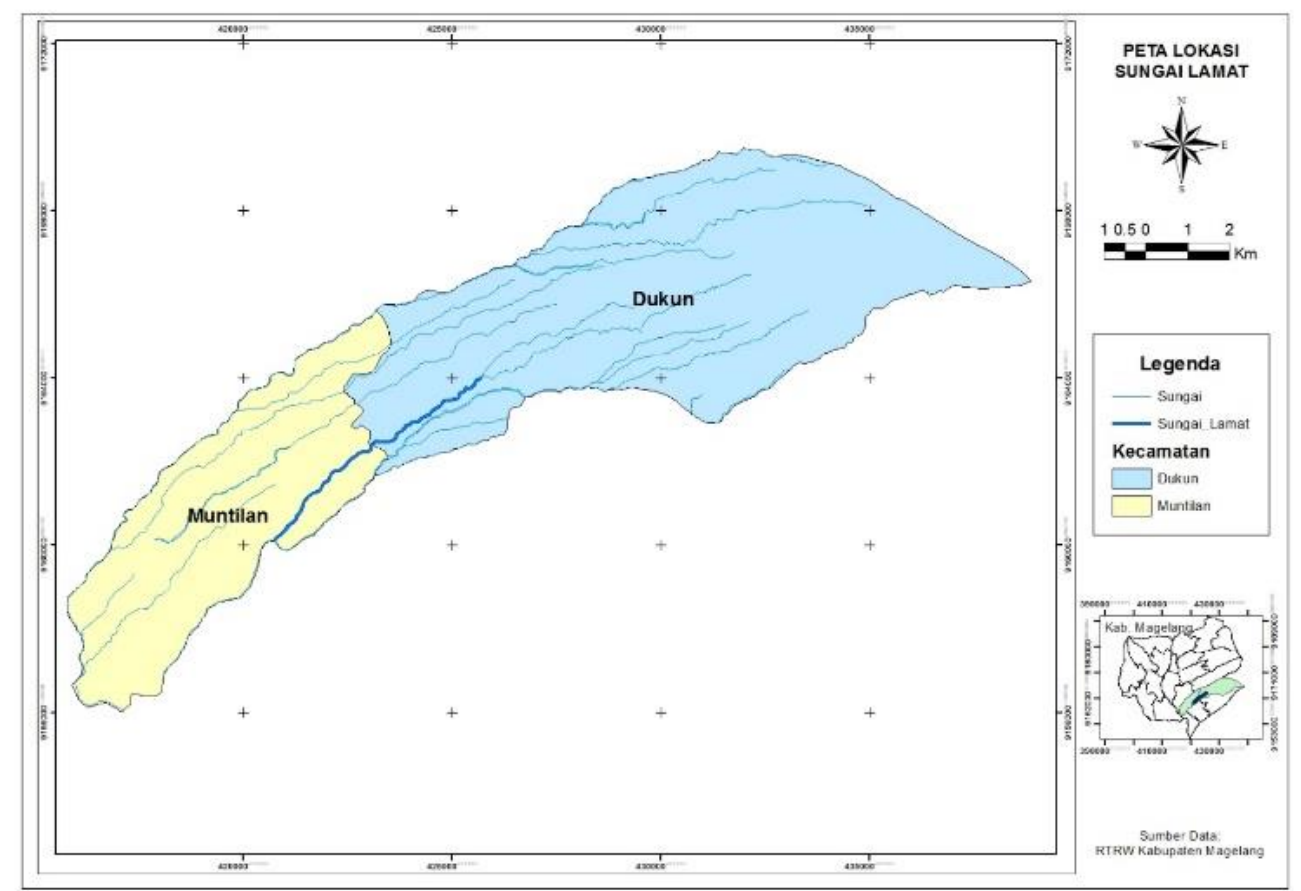

Gambar 1. Peta Lokasi Sungai Lamat 


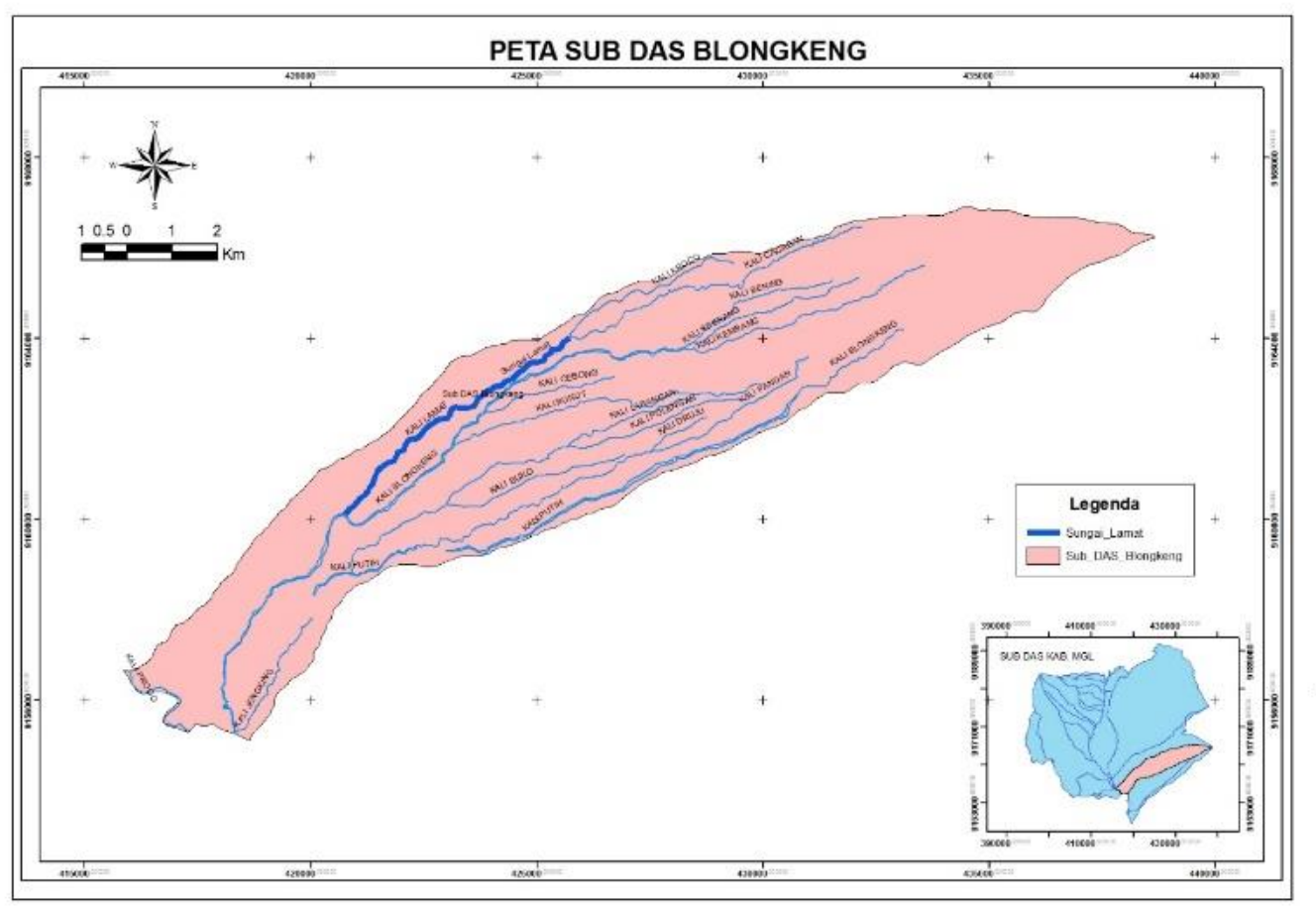

Gambar 2. Peta Sub DAS Blongkeng

\subsection{DAS Blongkeng}

DAS Blongkeng termasuk salah satu DAS yang memiliki beban pencemaran yang tinggi sehingga dapat dimasukkan ke dalam kriteria Sub DAS kritis (BLH, 2015). Tingginya beban pencemaran yang diterima oleh DAS Blongkeng dapat dilihat pada Gambar 3. Beban pencemaran dilihat dari 3 parameter, yaitu nilai Biological Oxygen Demand (BOD), Chemical Oxygen Demand (COD), dan Total Suspended Solid (TSS). Bila dilihat pada grafik (Gambar 3), nilai COD yang yang masuk ke Sub DAS Blongkeng > $3.000 \mathrm{~kg} / \mathrm{hr}$, nilai BOD hampir mendekati $3.000 \mathrm{~kg} / \mathrm{hr}$, sedangkan nilai TSS > 1.000 $\mathrm{kg} / \mathrm{hr}$.

Apabila dilihat pada Gambar 4, penggunaan lahan di Sub DAS Blongkeng terdiri atas air tawar, semak belukar, gedung, hutan, kebun, pemukiman, rumput, sawah irigasi, sawah tadah hujan, tanah berbatu dan tegalan. Lahan di sekitar Sungai Lamat yang berada di Kecamatan Dukun didominasi persawahan irigasi. Ada pula area pemukiman walaupun sedikit. Sedangkan di Kecamatan Muntilan, lahan di sekitar Sungai Lamat didominasi oleh pemukiman. Ada pula sedikit area sawah irigasi dan kebun. Penggunaan lahan yang didominasi pemukiman, sawah dan juga kebun ini berpotensi menjadi sumber pencemar bagi Sungai Lamat, baik berupa limbah cair maupun limbah padat. 


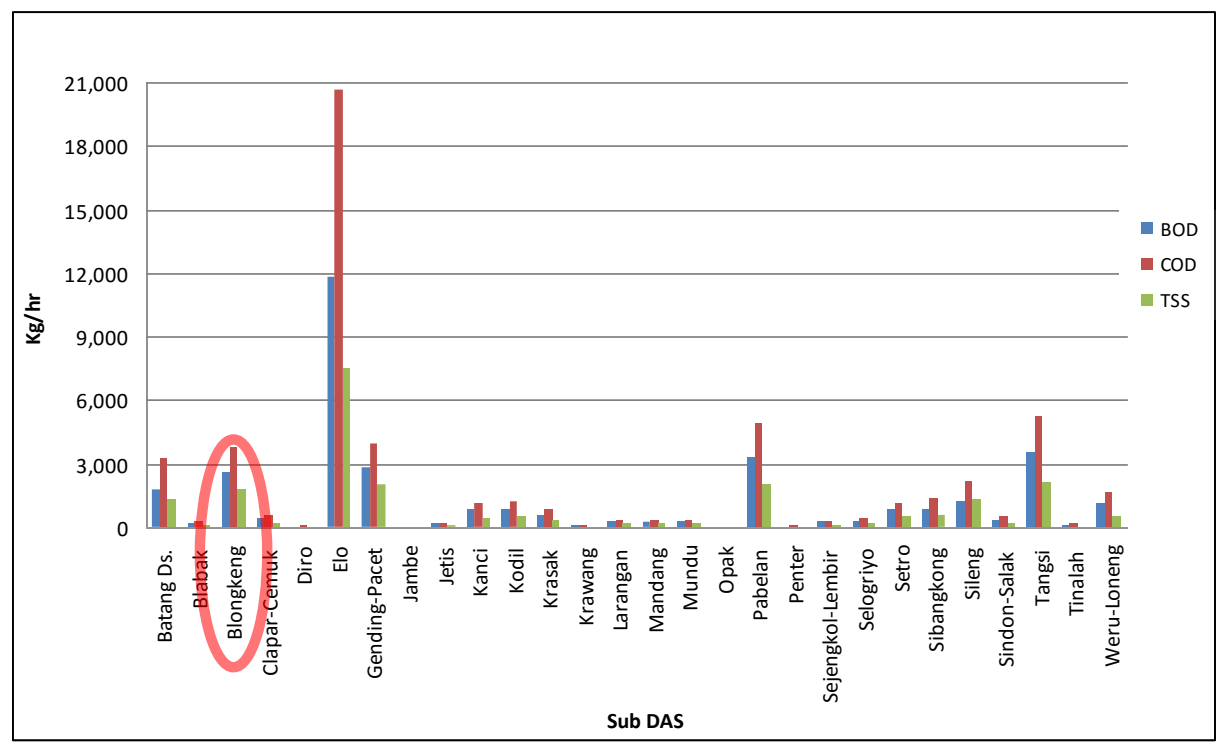

Gambar 3. Beban Pencemaran (kg/hari) di setiap Sub DAS Kab. Magelang (BLH, 2015)

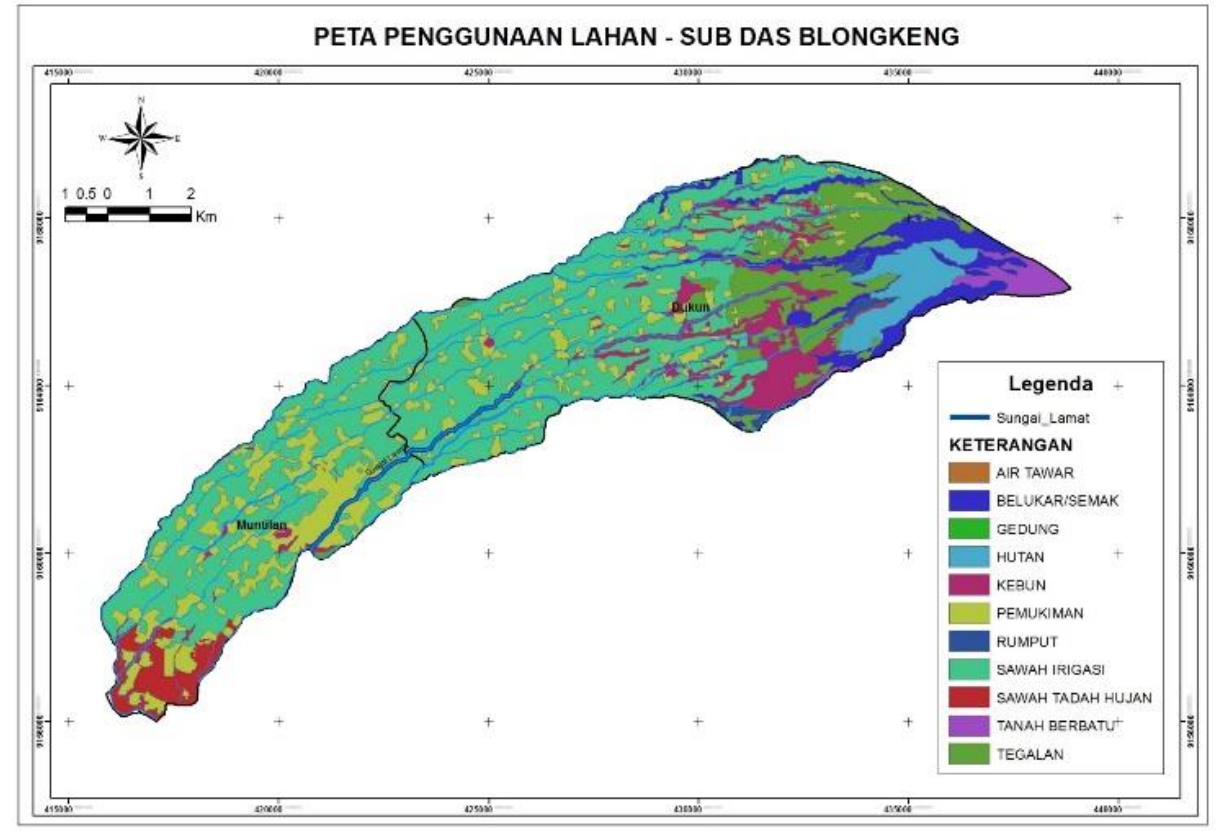

Gambar 4. Peta Penggunaan Lahan di Sub DAS Blongkeng

\subsection{Sumber Pencemar Sungai Lamat}

Berdasarkan pengamatan yang dilakukan, di sekitar Sungai Lamat ditemukan beberapa titik sumber pencemar, baik itu berasal dari limbah cair maupun limbah padat. 


\section{a. Limbah cair}

Limbah cair yang berpotensi mencemari Sungai Lamat berasal dari industri di sekitar sungai dan juga limbah domestik yang langsung dibuang ke sungai. Limbah industri yang dimaksud di sini berasal dari usaha kecil masyarakat. Masyarakat juga ada yang langsung membuang limbah cair rumah tangga ke dalam sungai melalui pipa-pipa Limbah cair ini walaupun tidak langsung dibuang ke sungai, namun berpotensi mencemari lingkungan karena limbah tersebut dialirkan ke selokan.

Masyarakat di sekitar sungai juga ada yang langsung membuang limbah cair rumah tangga ke dalam sungai melalui pipa-pipa seperti yang ditunjukkan pada Gambar 5.
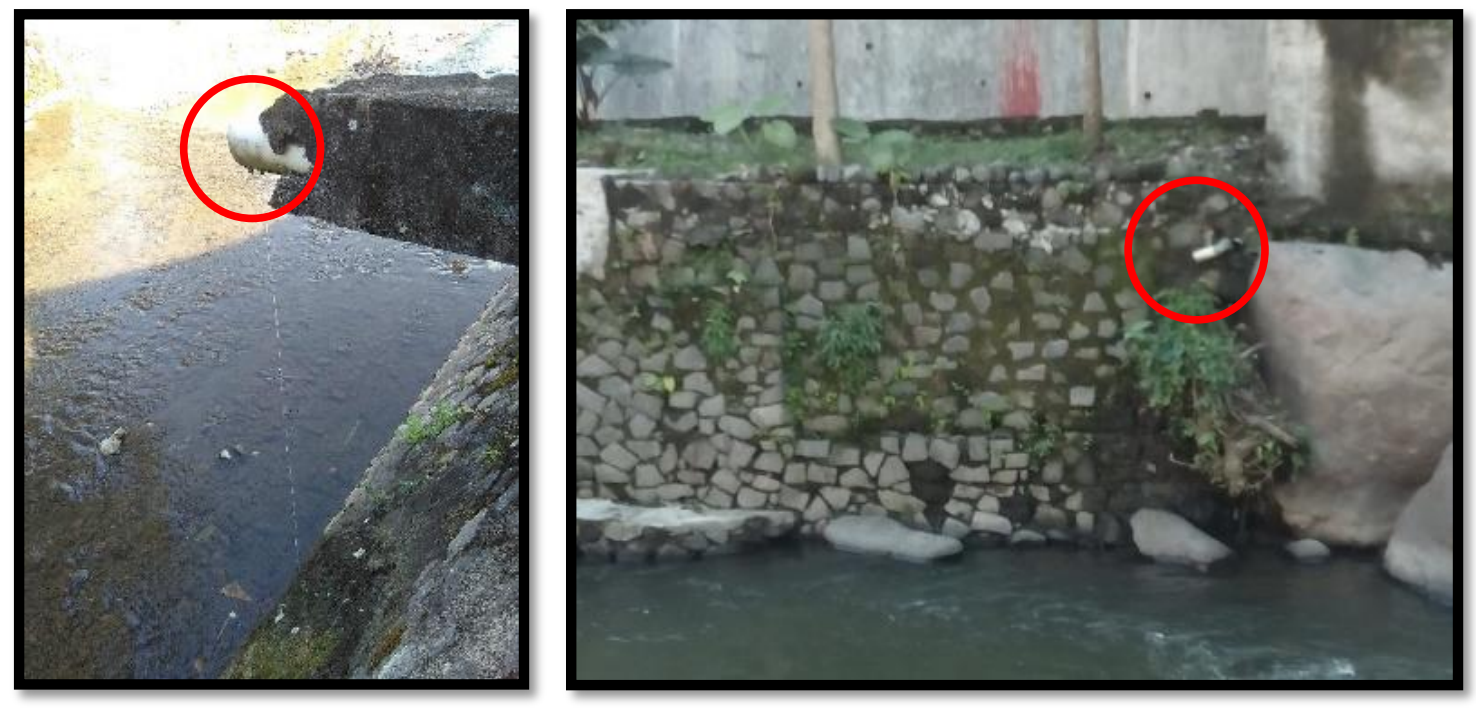

Gambar 5. Pembuangan Limbah Cair ke Sungai Lamat

b. Limbah padat

Di sekitar Sungai Lamat ini juga ditemukan banyak sekali timbulan sampah/limbah padat. Masyarakat menjadikan lahan kosong ataupun kebun yang berada di sepanjang sungai sebagai tempat pembuangan sampah (Gambar 6). Sampah yang berada di sekitar sungai ini dapat terbawa arus sungai sehingga mencemari sungai. Timbulan sampah ini juga lama-kelamaan akan mengeluarkan leachate (air lindi/air sampah) yang berbahaya bagi kelestarian tanah dan air. 

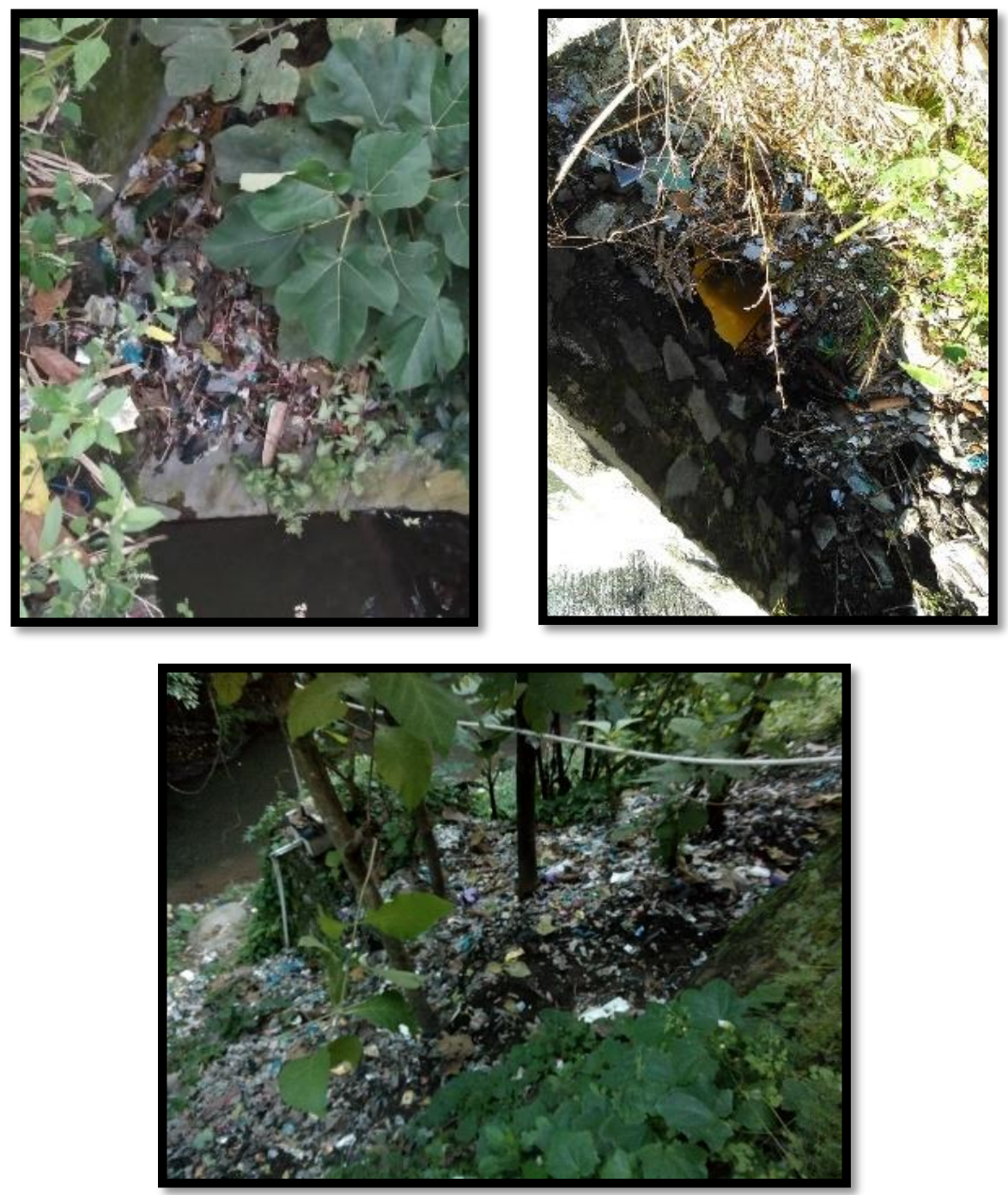

Gambar 6. Timbulan Sampah di Sekitar Sungai Lamat

\subsection{Pemetaan Pencemaran Sungai Lamat}

Berdasarkan hasil pengamatan yang dilakukan, ditemukan beberapa titik lokasi yang berpotensi mencemari Sungai Lamat. Titik lokasi ini kemudian diambil koordinatnya. Data koordinat tiap sumber pencemar diolah menggunakan Sistem Informasi Geografis (SIG) dan hasilnya berupa Peta Sumber Pencemar Sungai Lamat yang dapat dilihat pada Gambar 7. Sungai Lamat merupakan pertemuan antara 2 sungai yaitu Sungai Kroco dan Sungai Cacaban. Sungai Lamat melewati 4 desa yang berada di 2 kecamatan. Desa-desa yang dilewati Sungai Lamat adalah Desa Ngadipuro dan Desa Ketunggeng 
yang berada di Kecamatan Dukun, serta Desa Muntilan dan Desa Gunungpring yang berada di Kecamatan Muntilan.

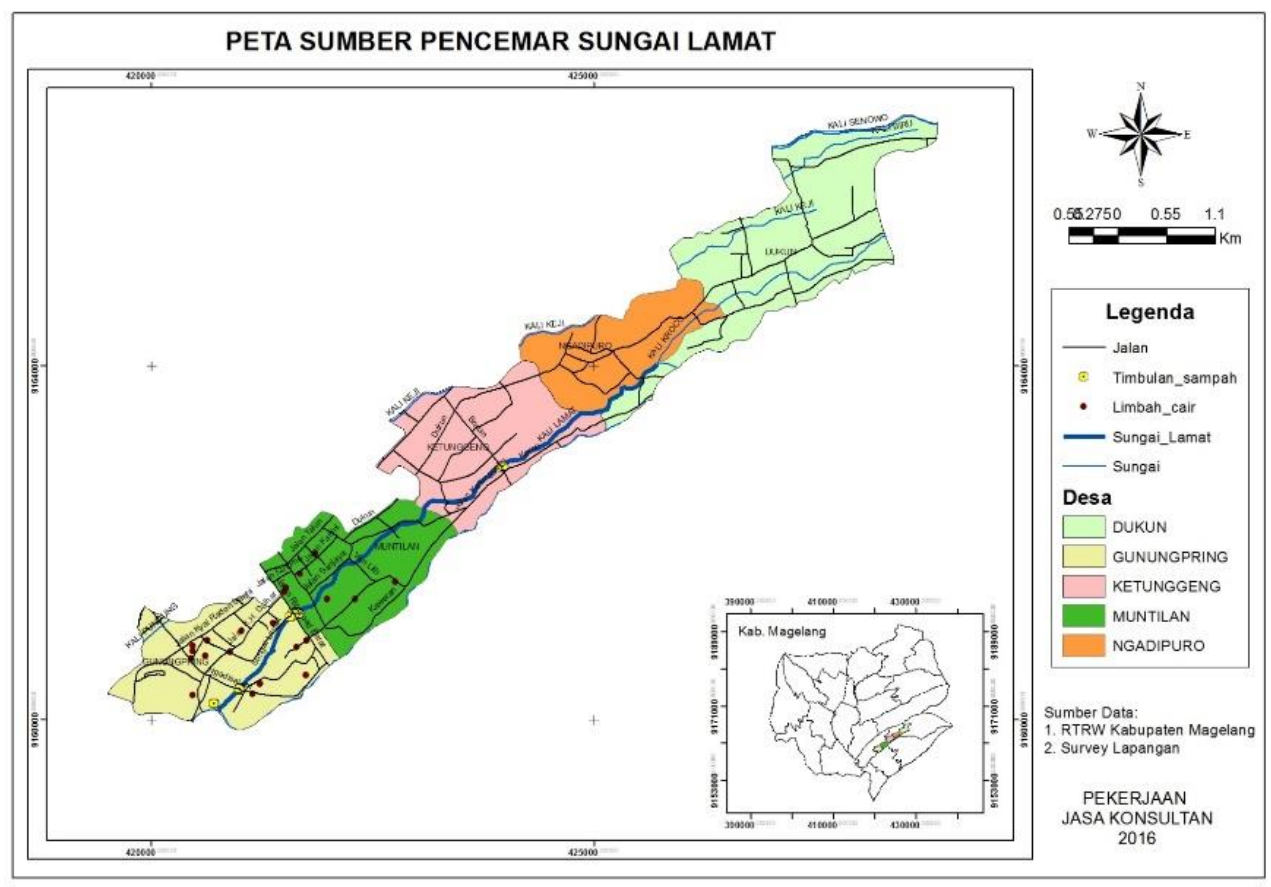

Gambar 7. Peta Sumber Pencemar Sungai Lamat

\subsection{Kualitas dan Mutu Air Sungai Lamat}

Data kualitas air Sungai Lamat diperoleh melalui pengumpulan data sekunder. Data yang diperoleh adalah kualitas air Sungai Lamat pada tahun 2011 - 2015. Titik sampel analisa kualitas air Sungai Lamat berada di daerah hulu, tengah, dan hilir. Data kualitas air ini kemudian dibandingkan dengan baku mutu. Baku mutu yang digunakan adalah baku mutu sesuai dengan Lampiran PP No 82 Tahun 2001. Setelah dibandingkan, diperoleh hasil bahwa ada beberapa parameter yang melebihi baku mutu yang dipersyaratkan. Hasil ini yang kemudian digunakan untuk menentukan status mutu air Sungai Lamat.

Penentuan status mutu air Sungai Lamat dilakukan dengan menggunakan Metode Indeks Pencemaran. Metode ini digunakan karena terdapat perbedaan pada parameter kualitas air yang diuji. Salah satu contohnya adalah parameter COD yang hanya diuji pada tahun 2014 dan 2015 sedangkan pada tahun 2011 - 2013 parameter ini tidak diuji. Hal ini menyebabkan data time series ini tidak dapat digunakan untuk penentuan status mutu air menggunakan Metode STORET. 
Skor Indeks Pencemaran (IP) Sungai Lamat tahun 2011-2015, apabila dibandingkan dengan baku mutu baik di hulu, tengah, maupun hilir menunjukkan hasil baik hingga cemar ringan. Tidak ada yang mencapai cemar sedang atau bahkan cemar berat. Grafik status mutu Sungai Lamat dapat dilihat pada Gambar 8 - Gambar 10.

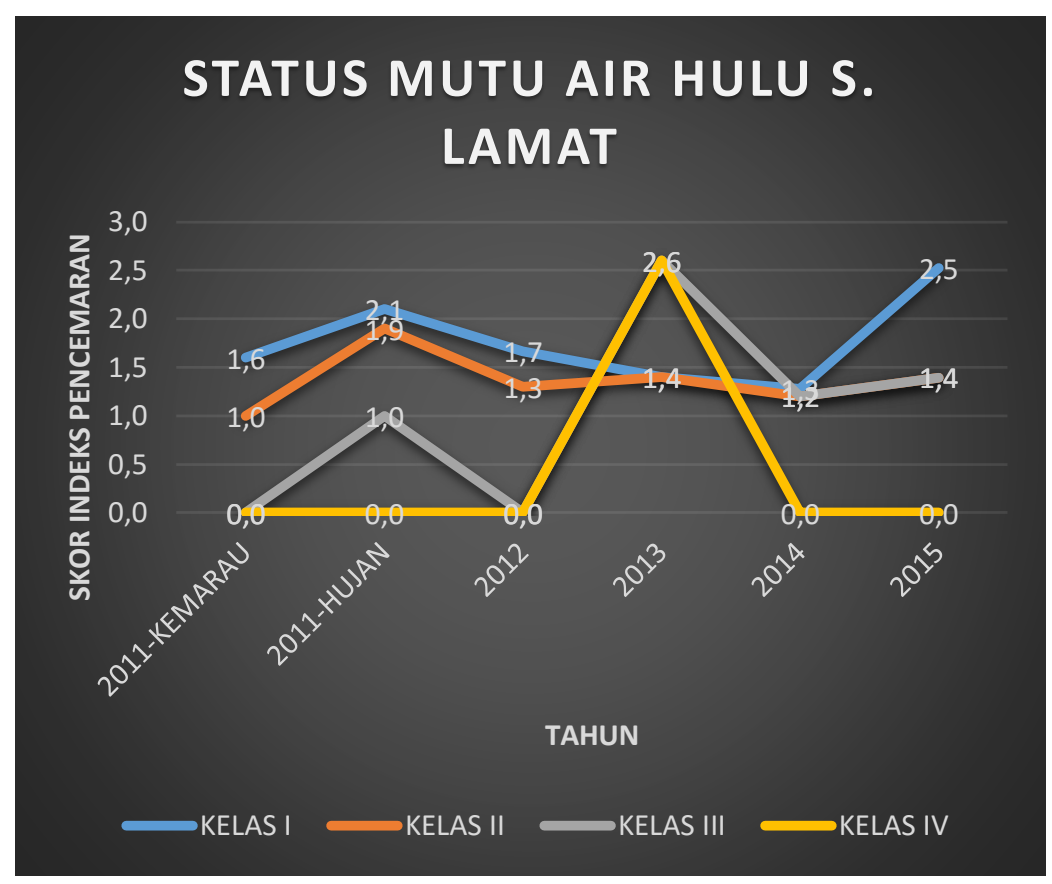

Gambar 8. Status Mutu Air Hulu Sungai Lamat

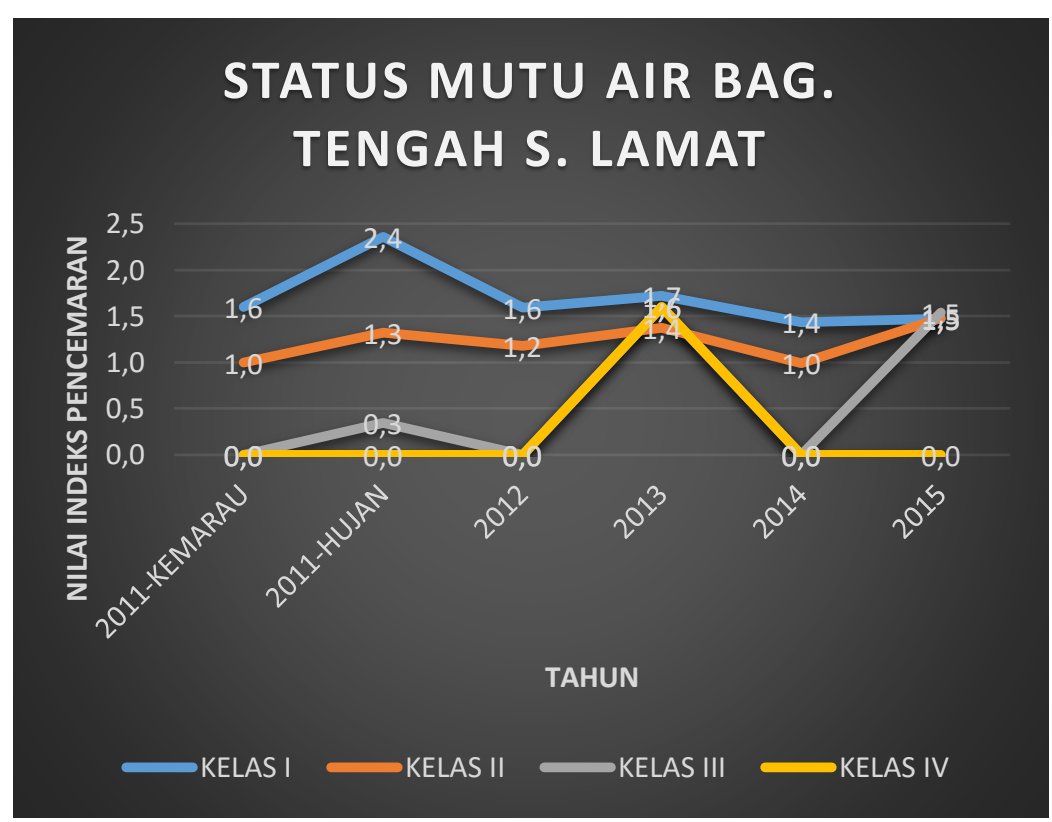

Gambar 9. Status Mutu Air Bagian Tengah Sungai Lamat 


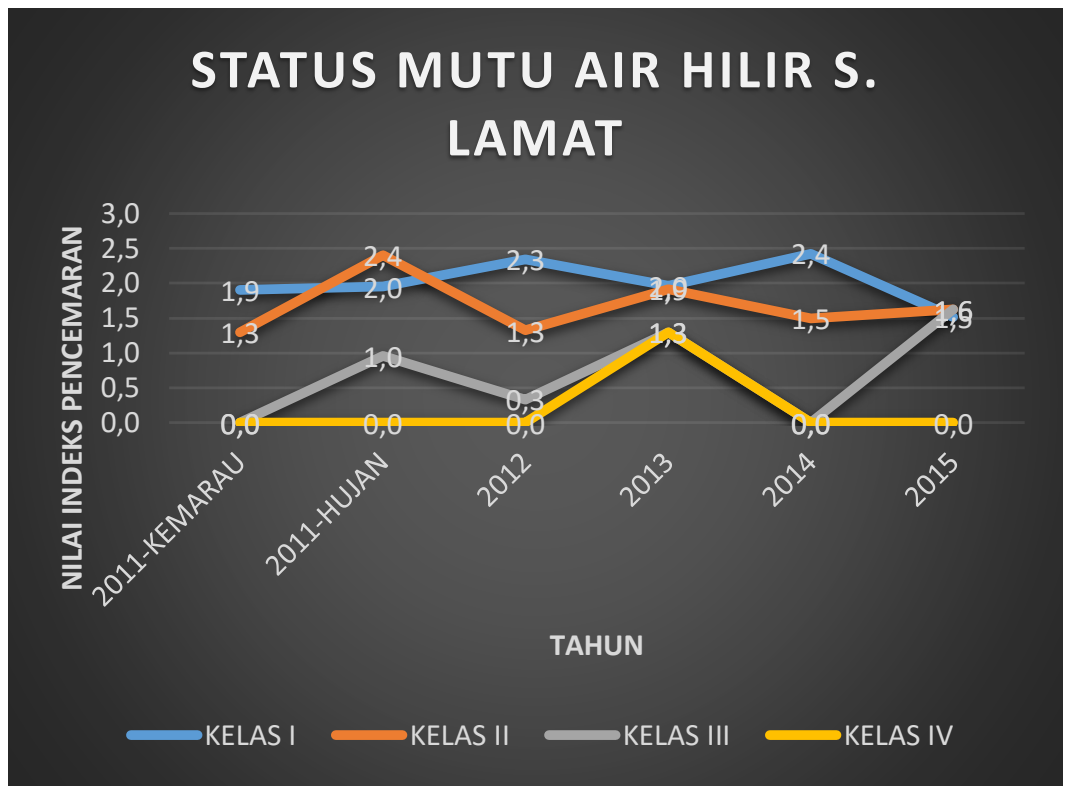

Gambar 10. Status Mutu Air Hilir Sungai Lamat

Status mutu air Sungai Lamat menunjukkan hasil dari "baik" hingga “cemar ringan”. Namun yang harus dicermati dari kualitas air ini adalah tingginya konsentrasi timbal. Konsentrasi timbal di bagian hulu pada tahun 2015 mencapai 0,51 mg/L, bagian tengah 0,6 mg/L dan di bagian hilir 0,4 mg/L. Konsentrasi ini tentu saja melebihi baku mutu air untuk kelas I, II dan III menurut PP No 82 Tahun 2001.

Sungai sebenarnya memiliki kemampuan "self purification", sehingga sungai yang tercemar tersebut dapat memulihkan dirinya sendiri dari zat-zat pencemar. Seharusnya skor Indeks Pencemar (IP) dari hulu ke hilir semakin menurun. Atau jika skor IP di bagian tengah lebih tinggi daripada di hulu, maka di hilir skor IP tersebut akan mengalami penurunan kembali. Namun apabila dilihat pada grafik pada Gambar 8-10, terkadang skor IP di hilir lebih tinggi daripada skor IP di hulu dan tengah. Hal ini kemungkinan terjadi karena pengaruh dari aktivitas penggunaan lahan di sekitar sungai sehingga menambah zat pencemar yang masuk ke sungai. Selain itu, dapat juga disebabkan morfologi Sungai Lamat yang tenang (tidak terlalu banyak turbulensi) dan juga jarak yang tidak terlalu panjang, sehingga proses "self purification" tidak berjalan optimal. Kondisi seperti ini juga ditemukan di Sungai Blukar, Kabupaten Kendal seperti penelitian yang dilakukan oleh Agustiningsih, et al. (2012). 
Salah satu usaha yang dapat dilakukan untuk mencegah supaya Sungai Lamat tidak mengalami pencemaran yang lebih buruk adalah dengan mengajak masyarakat untuk berpartisipasi melestarikan Sungai Lamat. Selain itu, pengelolaan Sungai Lamat ini harus melibatkan semua pihak, baik itu pemerintah, swasta, perguruan tinggi, Lembaga Swadaya Masyarakat (LSM), dan pihak-pihak lain. Langkah awal yang dapat dilaksanakan adalah membentuk kelembagaan yang dapat mengintegrasikan semua pihak, mewakili aspirasi masyarakat dan sifatnya semi otonom. Hal ini seperti yang dikemukakan oleh Brontowiyono, et al. (2010) pada pengelolaan Sungai Code di Yogyakarta.

\section{KESIMPULAN DAN SARAN}

\subsection{Kesimpulan}

a. Sumber pencemar Sungai Lamat berasal dari kegiatan rumah tangga masyarakat dan juga industri yang berupa limbah cair dan limbah padat.

b. Berdasarkan penentuan status mutu air menggunakan Metode Indeks Pencemaran, status mutu air Sungai Lamat dari tahun ke tahun bervariasi, dari baik hingga cemar ringan.

\subsection{Saran}

a. Perlu dilakukan sosialisasi kepada masyarakat mengenai pentingnya menjaga kelestarian sungai.

b. Ada sanksi tegas bagi pihak yang membuang limbah baik padat maupun cair di sekitar sungai.

c. Perlu dilakukan penataan di area sepanjang Sungai Lamat, misalnya dengan pembuatan taman di sempadan sungai.

\section{UCAPAN TERIMAKASIH}

Penelitian ini merupakan hasil kerjasama antara Akademi Teknik Tirta Wiyata dengan Badan Lingkungan Hidup (BLH) Kabupaten Magelang. Penulis mengucapkan terimakasih kepada BLH Kabupaten Magelang, atas segala bantuannya sehingga penelitian ini dapat dilaksanakan.

\section{DAFTAR PUSTAKA}

Agustiningsih, D., Sasongko, S. B. \& Sudarno, 2012. Analisis Kualitas Air dan Strategi Pengendalian Pencemaran Air Sungai Blukar Kabupaten Kendal. Jurnal Presipitasi, 9(2), pp. 64-71.

Asdak, C., 2010. Hidrologi dan Pengelolaan Daerah Aliran Sungai. Yogyakarta: Gadjah Mada University Press. 
BLH, 2015. Laporan Inventarisasi \& Identifikasi Limbah Cair, Kabupaten Magelang: BLH Kab. Magelang.

Brontowiyono, W., Kasam, L., R. \& A., I., 2013. Strategi Penurunan Pencemaran Limbah Domestik di Sungai Code DIY. Jurnal Sains dan Teknologi Lingkungan, 5(1), pp. 36-47.

Brontowiyono, W., Lupiyanto, R. \& Wijaya, D., 2010. Pengelolaan Kawasan Sungai Code Berbasis Masyarakat. Jurnal Sains dan Teknologi Lingkungan, 2(1), pp. 7-20.

Effendi, H., 2003. Telaah Kualitas Air Bagi Pengelolaan Sumber Daya dan Lingkungan Perairan. Yogyakarta: Kanisius.

KepMen LH No 115 Tahun 2003 Tentang Pedoman Penentuan Status Mutu Air.

UU No 82 Tahun 2001 Tentang Pengelolaan Kualitas Air dan Pengendalian Pencemaran Air.

Yogafanny, E., 2015. Pengaruh Aktifitas Warga di Sempadan Sungai terhadap Kualitas Air Sungai Winongo. Jurnal Sains dan Teknologi Lingkungan, 7(1), pp. 41-50. 